\title{
VALLEY-FILL SANDSTONES IN THE KOOTENAI FORMATION ON THE CROW INDIAN RESERVATION, SOUTH-CENTRAL MONTANA
}

\author{
Quarterly Technical Report \\ Report Period: 07/01/1997 through 09/30/1997 \\ Author: David A. Lopez \\ Report Issue Date: 10/01/1997 \\ DE-FG22-96BC14996 \\ Montana Bureau of Mines and Geology \\ MSU-Billings, Campus Box 112 \\ 1500 N 30th Street \\ Billings, MT 59101
}




\section{Disclaimer}

This report was prepared as an account of work sponsored by an agency of the United States Government. Neither the United States Government nor any agency thereof, nor any of their employees, makes any warranty, express or implied, or assumes any legal liability or responsibility for the accuracy, completeness, or usefulness of any information, apparatus, product, or process disclosed, or represents that its use would not infringe privately owned rights. Reference herein to any specific commercial product, process, or service by trade name, trademark, manufacturer, or otherwise, does not necessarily constitute or imply its endorsement, recommendation, or favoring by the United States Government or any agency thereof. The views and opinions of authors expressed herein do not necessarily state or reflect those of the United States Government or any agency thereof. 


\begin{abstract}
Subsurface data is being collected, organized, and a digital database is being prepared for the project. An ACCESS database and PC-Arcview will be used to manage and interpret the data.

All of the four 30' $X 60^{\prime}$ geologic quadrangles have been scanned to produce a digital surface geologic data base for the Crow Reservation and all are nearing completion. Writing of the map explanations has begun.

Field investigations were nearly completed during this quarter; only minor field checks remain. With the help of a student field assistant from the Crow Tribe, the entire project area was inventoried for the presence of valley-fill deposits in the Kootenai Formation. Field inventory has resulted in the identification of nine exposures of thick valley-fill deposits. These appear to represent at least four major westward-trending valley systems. All the channel localities have been measured and described in detail and paleocurrent data has been collected from all but one locality. In addition, two stratigraphic sections were measured in areas where channels are absent.
\end{abstract}




\section{Table of Contents}

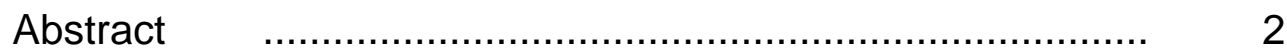

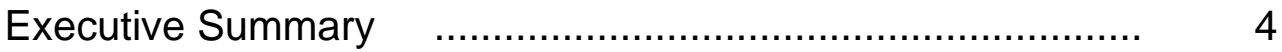

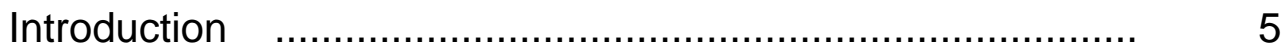

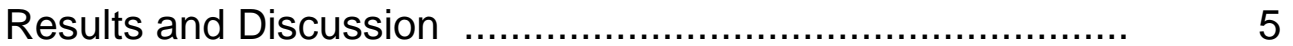

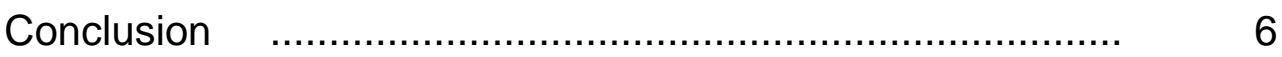




\section{Executive Summary}

Subsurface data is being collected, organized, and a digital database is being prepared for the project. An ACCESS database and PC-Arcview will be used to manage and interpret data.

All of the four 30' $X 60$ ' geologic quadrangles have been scanned to produce a digital surface geologic data base for the Crow Reservation and all are nearing completion. Writing of the map explanations has begun.

Field investigations were nearly completed during this quarter; only minor field checks remain. With the help of a student field assistant from the Crow Tribe, the entire project area was inventoried for the presence of valley-fill deposits in the Kootenai Formation. Field inventory has resulted in the identification of nine exposures of thick valley-fill deposits. These appear to represent at least four major westward-trending valley systems. All the channel localities have been measured and described in detail and paleocurrent data has been collected from all but one locality. In addition, two stratigraphic sections were measured in areas where channels are absent. 


\section{Introduction}

The stratigraphic study of the valley-fill sandstones in the Kootenai Formation was begun in August, 1996 with reconnaissance field work to locate the exposures of channel sandstone deposits. Subsurface aspects of the project were begun in the second quarter and are continuing.

Digitization of surface geologic maps of the Crow Reservation area continues, as well as processing and editing of the data. An oil and gas training seminar for Crow Tribal members was completed in the third quarter.

\section{Results and Discussion}

Subsurface data collection was begun in the second quarter of this project, and continues this quarter. A collection of most of the oil and gas well logs for the Crow Reservation area was donated to the project by a company that had initiated an exploration program on the reservation several years ago. These have been filed and inventoried to determine missing well coverage. Preliminary regional subsurface cross sections have been constructed for correlation purposes and to identify channel facies.

A digital data base of commercially available "scout card" data has been generated using Microsoft Access. PC-Arcview will be used for map generation and interpretation.

Geologic maps of all four 30' X 60' quadrangles that encompass the Crow Reservation have been digitally scanned for the geologic data base that will be provided to the Crow Tribe. These are all nearing completion. The map explanations for these maps are currently being compiled,

Field investigations for this field season were begun during the last quarter. To help with these investigations a field assistant was employed as described in the original project proposal. Marzha Fritzler, a member of the Crow Tribe and a student at Haskell Indian Nations University in Liberal, Kansas was selected for this position.

Field investigations were nearly completed during this quarter; only minor field checks remain. With the help of the student field assistant from the Crow Tribe, the entire project area was inventoried for the presence of valley-fill deposits in the Kootenai Formation. Field inventory has resulted in the identification of nine exposures of major valley-fill deposits. These appear to represent at least four major westward-trending valley systems. All the channel localities have been measured and described in detail and paleocurrent data has been collected from all but one locality. In addition, two stratigraphic sections were measured in areas where channels are absent. Preliminary versions of all the measured sections have all been digitally plotted using LogPlot97 by Rockware.

Reconnaissance investigations of valley-fill deposits in the Bighorn Basin to the west have also been conducted. Preliminary results indicate that some of 
these channels appear to be continuations of the channels identified on the Crow Reservation.

\section{Conclusion}

Subsurface data is being collected, organized, and a digital database is being prepared for the project. The database will be managed with Microsoft Access; PC-Arcview will be used for map generation and interpretation.

All four 30' X 60' geologic quadrangles have been scanned to produce a digital surface geologic data base for the Crow Reservation. All quadrangles are nearing completion and the map explanations are being compiled.

Field investigations were nearly completed this quarter and have been very successful in identifying significant exposures of valley-fill sandstones. At least four major westward-trending valley systems have been identified. Measured sections of all localities have been completed. 